\title{
Postharvest Irradiation Enhances Anthocyanin Synthesis in Apples But Not in Pears
}

\author{
Evelyn Marais, Gerard Jacobs, and Deirdre M. Holcroft ${ }^{1}$ \\ Department of Horticultural Science, University of Stellenbosch, P. Bag X1, \\ Matieland 7602, Stellenbosch, South Africa
}

Additional index words. Malus $\times$ domestica, Pyrus communis, red blush, color, hue angle, light

\begin{abstract}
Cripps' Pink' apples (Malus $\times$ domestica Borkh.) subjected to 72 hours of postharvest irradiation developed a better red blush with high pressure sodium (HPS) (hue angle $56.5^{\circ}$ ) than with $\mathrm{UV}$-B plus incandescent (UVB+I) lamps (hue angle $70.7^{\circ}$ ). Only HPS lamps were used in subsequent experiments. The increase in red color (hue angle decrease of $14.9^{\circ}$ ) in 'Braeburn' apples held at $-0.5^{\circ} \mathrm{C}$ for 8 weeks prior to treatment was smaller than in fruit stored for 4 weeks (hue angle decrease of $23^{\circ}$ ). No increase in color or anthocyanin concentration was observed in 'Forelle' pears (Pyrus communis $L$.) that were similarly treated. 'Forelle' pears were harvested with or without attached stem and leaves to determine whether precursor availability restricted postharvest color development. Fruit were irradiated with HPS at $20 / 20{ }^{\circ} \mathrm{C}$ and $20 / 6{ }^{\circ} \mathrm{C}$ (day/night) for 168 hours. The absence of leaves hastened the decrease in hue angle, but this was due to yellowing and not to development of red blush. Since 'Forelle' pears showed no response to light after harvest, two fully red cultivars, Bon Rouge and Red Anjou, were irradiated with HPS lamps for 72 hours. Hue angle was not affected by irradiation. Thus, anthocyanin synthesis was stimulated by postharvest irradiation with HPS lights in apples, but not in pears.
\end{abstract}

Development of red color in the skin of pome fruit is associated with accumulation of anthocyanin pigment, while overall fruit color is a result of the interaction between anthocyanin, carotenoid and chlorophyll pigments (Lancaster et al., 1994). Typically, pome fruit contain cyanidin derivatives, particularly cyanidin 3-galactoside, although trace amounts of peonidin have been identified in some pear cultivars (Dussi et al., 1995; Macheix et al., 1990).

Two main periods of anthocyanin synthesis occur during apple development. The first occurs in young fruit during cell division and is considered commercially unimportant. The second occurs during maturation and ripening when anthocyanin concentrations can increase as much as five-fold (Knee, 1972; Lancaster, 1992; Reay et al., 1998). In 'Forelle' pears, anthocyanin concentrations, measured in four production regions in South Africa, were high in the first few weeks of fruit development but steadily dropped over the production period, with no obvious second peak in synthesis (Viljoen, 1996).

Red pigmentation of apples can be improved after harvest using artificial lights. A range of wavelengths from UV-B (280-320 $\mathrm{nm})$ to red light $(680-780 \mathrm{~nm})$ is effective

Received for publication 21 Mar. 2000. Accepted for publication 28 Aug. 2000. The cost of publishing this paper was defrayed in part by the payment of page charges. Under postal regulations, this paper therefore must be hereby marked advertisement solely to indicate this fact.

${ }^{1}$ To whom requests for reprints should be addressed. E-mail address: dmh@maties.sun.ac.za
(Arakawa et al., 1985; Dong et al., 1995; Saks et al., 1990; Siegelman and Hendricks, 1958). Red light alone is only slightly effective in stimulating anthocyanin production, UV-B has considerable effect, and both together have synergistic effects (Arakawa et al., 1985).

The development of a red blush on at least one side of the fruit of some apple and pear cultivars is required for market acceptance. Since South Africa is in one of the warmest areas in the world producing pome fruit, achieving this color standard is a challenge to producers. Consequently, the purpose of this work was to improve our understanding of anthocyanin synthesis in pome fruit cultivars by using postharvest irradiation. We hypothesized that pears would respond to postharvest irradiation as do apples, and that red blush could be improved in 'Forelle' pears.

\section{Materials and Methods}

All fruit were harvested from farms located in the Western Cape, South Africa (lat. $33^{\circ} \mathrm{S}$, long. $19^{\circ} \mathrm{E}$ ), which has a Mediterranean climate. 'Forelle' pears, and 'Braeburn' and 'Cripps' Pink' (marketed as 'Pink Lady') apples were harvested from the inside of trees on three different farms near Ceres. Poorly colored 'Red Anjou' and 'Bon Rouge' pears were picked from orchards near Ceres, and 'Forelle' pears used in a separate experiment were harvested from an orchard in Somerset West.

Expt. 1. 'Cripps' Pink' and 'Braeburn' apples, 'Forelle' pear. 'Cripps' Pink' apples were subjected to UV-B $(4 \times 40 \mathrm{~W}$ bulbs, 280 nm, FL 20 SLB/18 chemical; Taiwan Fluores- cent Company, Taipei, Taiwan) plus incandescent light $(4 \times 60 \mathrm{~W}, 380-720 \mathrm{~nm}$; Osram, Munich, Germany) (UVB+I) or HPS light $(400 \mathrm{~W}$, SON-T, Osram) immediately after harvest. The light intensity of the HPS was 22 $24 \mathrm{~W} \cdot \mathrm{m}^{-2}$ as measured by a Decagon light meter (AccuPAR ver. 4.1; Decagon Devices, Pullman, Wash.) $\approx 1 \mathrm{~m}$ from the light source. The light intensity of the UVB+I could not be measured with this equipment. 'Braeburn' apples and 'Forelle' pears were harvested and stored for either 4 or 8 weeks at $-0.5^{\circ} \mathrm{C}$ before irradiation with HPS lights. Experiments on 'Cripps' Pink', 'Braeburn', and 'Forelle' were conducted in growth chambers set at $18 \pm 2{ }^{\circ} \mathrm{C}$. Lights were placed on top of the chamber with an acrylic (Perspex) layer between the lights and the fruit. In each experiment, 24 fruit (six replicates of four fruit each) were used.

Circles were marked on the unblushed side of the fruit and external color was measured initially with a chromameter (NR-3000; Nippon Denshoku, Tokyo). Color was measured again immediately after 24,48 , and $72 \mathrm{~h}$ of irradiation. Fruit was stored at $0{ }^{\circ} \mathrm{C}$ for 2 weeks before removal of the peel for anthocyanin analysis. Although lightness, chroma, and hue were recorded, usually only hue angle $\left(\mathrm{h}^{\circ}=\operatorname{arctangent}[\mathrm{b} / \mathrm{a}]\right)$ is presented. Hue angle refers to the angle formed by a line from the origin to the intercept of the $a$ (x-axis) and $b$ (y-axis) coordinates, where $0^{\circ}=\mathrm{red}, 90^{\circ}=$ yellow, $180^{\circ}=$ green and $270^{\circ}=$ blue $(\mathrm{McGuire}$, 1992 ), and consequently is the most appropriate means of expressing the changes in color.

Fruit peel was frozen at $-80^{\circ} \mathrm{C}$, lyophilized and ground to a fine powder. Anthocyanin extraction was based on the procedure of Siegelman and Hendricks (1958). Fifteen milliliters of a $1 \% \mathrm{HCl}$ in methanol solution was added to $0.5 \mathrm{~g}$ of sample and left for $18 \mathrm{~h}$ at 5 ${ }^{\circ} \mathrm{C}$ in the dark. Samples were centrifuged for $10 \mathrm{~min}$ at $12,000 \mathrm{~g}_{\mathrm{n}}$. Absorbance of the supernatant was measured at $530 \mathrm{~nm}$ with a spectrophotometer $\left(\mathrm{DU}^{\circledR}\right.$ Series 64 ; Beckman, Fullerton, Calif.). A standard curve was obtained with idaein chloride (cyanidin 3-galactoside) (Carl Roth, Karlsruhe, Germany), and anthocyanin concentration was expressed as $\mu \mathrm{g} \cdot \mathrm{g}^{-1}$ DW of peel.

A hand-held penetrometer (Southtrade FT327, Alphonsine, Italy) fitted with a 11-mm tip for apples and an 8-mm tip for pears, was used to measure firmness. Fruit were weighed before and after irradiation to determine water loss.

Expt. 2 'Forelle' pear. 'Forelle' pears were also used in an experiment designed to determine whether precursor availability can affect postharvest color development. Fruit were harvested with or without attached stem and leaves. Half of the fruit without leaves were wrapped in foil. The stems of fruit with leaves (5-6) were placed in water and the entire fruit was covered with plastic to prevent moisture loss. Fruit were irradiated with HPS lights at two temperature regimes, $20 / 20^{\circ} \mathrm{C}$ or $20 / 6^{\circ} \mathrm{C}$ (day/night). Color was measured in the marked circles at the beginning of the experiment, and again after $168 \mathrm{~h}(7 \mathrm{~d})$. Three replicates of four fruit were used for each treatment. 
Expt. 3 'RedAnjou' and 'Bon Rouge' pear. Forty poorly colored 'Red Anjou' and 'Bon Rouge' pears were placed in a growth chamber at $20{ }^{\circ} \mathrm{C}$ immediately after harvest. Half were irradiated with HPS lights for $72 \mathrm{~h}$ and half were not. Circles were marked on the fruit, and color was measured at the start of the experiment and again every $24 \mathrm{~h}$ for $72 \mathrm{~h}$.

Statistical analysis. Statistical analysis was performed on difference in hue angle and anthocyanin concentrations, using the General Linear Models (GLM) procedure (SAS Institute, 1996).

\section{Results and Discussion}

Expt. 1A. 'Cripps' Pink' apples. Red color development in 'Cripps' Pink' apples improved with increasing periods of irradiation, but the response was affected by lamp type. The hue angle $\left(4.2^{\circ}\right)$ of fruit subjected to $\mathrm{UVB}+\mathrm{I}$ had decreased slightly after $72 \mathrm{~h}$ of irradiation $(P<0.0397)$. Irradiation with HPS lamps resulted in much redder fruit; hue angle had decreased by $30^{\circ}$ to a final value of $56.5^{\circ}$ after $72 \mathrm{~h}$ of irradiation (Table 1). The increase in anthocyanin concentration was slower with UVB+I irradiation, reaching a maximum concentration of $155.9 \mathrm{mg} \cdot \mathrm{g}^{-1}$ after $72 \mathrm{~h}$ exposure vs. $271.8 \mu \mathrm{g} \cdot \mathrm{g}^{-1}$ following exposure to HPS lights (Table 1).

In preliminary experiments using UVB+I light, we were unable to stimulate anthocyanin synthesis in apples, contrary to published data (Arakawa et al., 1985, 1986; Chalmers and Faragher, 1977; Dong et al., 1995; Saks et al., 1990). Consequently, HPS and UVB+I lights were compared. Since the former were more effective in stimulating anthocyanin synthesis, they were used for the remainder of the work. The UV light was probably absorbed by the acrylic layer between the light source and the fruit, but this could not be confirmed.

Expt. 1B. 'Braeburn' apples. 'Braeburn' apples stored at $-0.5^{\circ} \mathrm{C}$ for 4 weeks prior to irradiation were significantly redder (hue angle decrease of $23^{\circ}$ ), and anthocyanin concentration had more than doubled, after $72 \mathrm{~h}$ of irradiation with HPS light (Table 2). Although red color also increased in fruit stored at $-0.5^{\circ} \mathrm{C}$ for 8 weeks prior to irradiation (hue angle change of $14.7^{\circ}$ ), the increase was significantly less than for fruit stored for 4 weeks. The initial hue angle of apples stored for 8 weeks prior to irradiation was similar to that of fruit stored for 4 weeks, but the initial anthocyanin concentration was higher. This had increased $\approx 40 \%$ after $72 \mathrm{~h}$ of irradiation.

From a practical point of view, fruit used in postharvest irradiation experiments are frequently stored at low temperatures prior to exposure to light, as described by Dong et al. (1995). Low temperature plays a major role in anthocyanin synthesis (Blankenship, 1987; Creasy, 1968; Lancaster, 1992; Saure, 1990). Bishop and Klein (1975) found that the ability of apples to synthesize anthocyanin under light decreased sigmoidally with time of storage prior to irradiation. Arthur (1932) found that fruit did not color after $\approx 7-8$ weeks of cold storage. Although the response of our

Table 1. Effects of irradiation with either UV-B plus incandescent lights (UV-B+I) or high-pressure sodium lights (HPS), on the hue angle and anthocyanin concentration of 'Cripps' Pink' apples irradiated immediately after harvest. Control fruit were held in the dark for $72 \mathrm{~h}$ prior to measurement (Expt. 1).

\begin{tabular}{lcccc}
\hline \hline $\begin{array}{l}\text { Irradiation } \\
\text { treatment }\end{array}$ & $\begin{array}{c}\text { Duration of } \\
\text { irradiation }(\mathrm{h})\end{array}$ & $\begin{array}{c}\text { Final hue } \\
\text { angle }\left(^{\circ}\right)\end{array}$ & $\begin{array}{c}\Delta \text { hue } \\
\text { angle }\left(^{\circ}\right)\end{array}$ & $\begin{array}{c}\text { Anthocyanin } \\
\text { concn }\left(\mu \mathrm{g} \cdot \mathrm{g}^{-1}\right)\end{array}$ \\
\hline UVB+I & 24 & 76.0 & 0.1 & 113.1 \\
& 48 & 77.7 & -1.0 & 100.6 \\
& 72 & 70.7 & -4.2 & 155.9 \\
Dark control & 72 & 84.7 & 0.7 & 85.6 \\
HPS & 24 & 79.6 & -0.4 & 125.7 \\
& 48 & 63.9 & -15.3 & 174.1 \\
Dark control & 72 & 56.5 & -30.0 & 271.8 \\
& 72 & 70.9 & 1.6 & 96.6 \\
Within UVB+I & & Significance & & \\
Within HPS & & --- & 0.0397 & 0.0728 \\
UVB+I vs HPS after $72 \mathrm{~h}$ & & ---- & 0.0001 & 0.0001 \\
& & & 0.0001 & 0.0001 \\
\hline
\end{tabular}

Table 2. Effects of irradiation with high pressure sodium lights (HPS) on the hue angle and anthocyanin concentration of 'Braeburn' apples and 'Forelle' pears stored for 4 or 8 weeks at $-0.5^{\circ} \mathrm{C}$ before treatment (Expt. 1B-C).

\begin{tabular}{|c|c|c|c|c|}
\hline $\begin{array}{l}\text { Time at }-0.5{ }^{\circ} \mathrm{C} \\
\text { prior to irradiation (wk) }\end{array}$ & $\begin{array}{c}\text { Duration of } \\
\text { irradiation }(\mathrm{h})\end{array}$ & $\begin{array}{l}\text { Final hue } \\
\text { angle }\left(^{\circ}\right)\end{array}$ & $\begin{array}{c}\Delta \text { hue } \\
\text { angle }\left({ }^{\circ}\right)\end{array}$ & $\begin{array}{c}\text { Anthocyanin concn } \\
\left(\mu g \cdot g^{-1}\right)\end{array}$ \\
\hline \multicolumn{5}{|c|}{ Braeburn apples } \\
\hline \multirow[t]{4}{*}{4} & 0 & 107.9 & -0.6 & 95.2 \\
\hline & 24 & 97.4 & -11.7 & 116.7 \\
\hline & 48 & 94.7 & -14.2 & 131.5 \\
\hline & 72 & 85.4 & -23.0 & 211.2 \\
\hline \multirow[t]{5}{*}{8} & 0 & 104.3 & -2.1 & 122.8 \\
\hline & 24 & 102.9 & -2.6 & 106.8 \\
\hline & 48 & 99.5 & -7.6 & 110.3 \\
\hline & 72 & 91.8 & -14.9 & 172.4 \\
\hline & \multicolumn{3}{|c|}{ Significance } & \\
\hline Within 4 wks & & --- & 0.0001 & 0.0001 \\
\hline Within 8 wks & & --- & 0.0001 & 0.0001 \\
\hline \multirow[t]{2}{*}{4 vs. 8 weeks after 72 h } & & --- & 0.0001 & 0.0073 \\
\hline & \multicolumn{4}{|c|}{ Forelle pears } \\
\hline 4 & 0 & 107.9 & -2.2 & 151.4 \\
\hline \multirow{7}{*}{8} & 24 & 107.9 & 5.1 & 132.1 \\
\hline & 48 & 107.4 & -1.4 & 133.0 \\
\hline & 72 & 107.9 & 0.5 & 171.6 \\
\hline & 0 & 107.5 & 3.2 & 159.5 \\
\hline & 24 & 105.5 & 0.6 & 146.8 \\
\hline & 48 & 102.7 & -2.3 & 163.2 \\
\hline & 72 & 100.4 & -4.5 & 166.0 \\
\hline \multicolumn{5}{|c|}{ Significance } \\
\hline Within 4 wks & & --- & 0.0992 & 0.1055 \\
\hline Within 8 wks & & --- & 0.0001 & 0.7906 \\
\hline 4 vs. 8 weeks after $72 h$ & & --- & 0.0001 & 0.8132 \\
\hline
\end{tabular}

fruit to postharvest irradiation was less intense after 8 weeks at $-0.5{ }^{\circ} \mathrm{C}$, the hue angle still decreased. Ground color changed from green to yellow as storage was prolonged, as a result of chlorophyll degradation.

Expt. 1C. 'Forelle' pears. In contrast to results with both 'Cripps' Pink' and 'Braeburn' apples, no increase in red color was observed in 'Forelle' pears irradiated after 4 or 8 weeks at $-0.5{ }^{\circ} \mathrm{C}$; hue angle decreased only slightly (Table 2). Although these decreases were statistically significant for fruit stored for 8 weeks, hue angle changed from $104^{\circ}$ to $100^{\circ}$, indicating yellowing, rather than red color development. Anthocyanin concentrations were similar between irradiation times and storage periods (Table 2). Although anthocyanin concentration did not increase in response to irradiation, the initial concentration was higher in 'Forelle' pears at the start of the experiment than in 'Cripps' Pink' (Table 1) or 'Braeburn' (Table 2) apples. Masking of anthocyanin pigments by chlorophyll has been suggested as an explanation for poor color. However, temperature and irradiation treatments often caused a reduction in chlorophyll, increasing the visibility of anthocyanin. 
Table 3. Effect of irradiation with high pressure sodium lights (HPS) for $168 \mathrm{~h}$ at $6{ }^{\circ} \mathrm{C} / 20^{\circ} \mathrm{C}$ or $20^{\circ} \mathrm{C}$ on color development of 'Forelle' pears either still attached to a stem segment with leaves, or without the stem segment but with or without foil (Expt. 2).

\begin{tabular}{|c|c|c|c|c|c|}
\hline \multirow[b]{2}{*}{ Treatments } & \multirow{2}{*}{$\begin{array}{r}6 / 20^{\circ} \mathrm{C} \\
\text { Final value } \\
\end{array}$} & \multicolumn{3}{|c|}{$20^{\circ} \mathrm{C}$} & \multirow[b]{2}{*}{ Significance } \\
\hline & & $\Delta$ Value & Final value & $\Delta$ Value & \\
\hline \multicolumn{6}{|c|}{ Hue } \\
\hline Pears + stem & 110.0 & -5.6 & 108.5 & -3.0 & 0.0707 \\
\hline Pears - foil & 102.6 & -12.3 & 107.7 & -8.6 & 0.0699 \\
\hline Pears + foil & 113.9 & -1.5 & 113.1 & -3.3 & 0.1278 \\
\hline Significance & --- & 0.0001 & --- & 0.0133 & \\
\hline \multicolumn{6}{|c|}{ Lightness } \\
\hline Pears + stem & 65.0 & 2.6 & 65.2 & 2.3 & 0.7557 \\
\hline Pears - foil & 61.1 & -2.6 & 62.9 & 0.0 & 0.1624 \\
\hline Pears + foil & 64.8 & 1.6 & 66.7 & 3.5 & 0.2488 \\
\hline Significance & --- & 0.0227 & --- & 0.0834 & \\
\hline \multicolumn{6}{|c|}{ Chroma } \\
\hline Pears + stem & 48.4 & 3.6 & 46.2 & 1.6 & 0.2274 \\
\hline Pears - foil & 42.8 & -5.2 & 44.2 & -3.3 & 0.3761 \\
\hline Pears + foil & 47.3 & 0.1 & 47.0 & -0.7 & 0.3199 \\
\hline Significance & --- & 0.0083 & --- & 0.0024 & \\
\hline
\end{tabular}

Fruit firmness was not affected by irradiation treatments (data not shown). Water loss increased with treatment, but never exceeded $1 \%$ in apples. Water loss was slightly more severe in 'Forelle' pears, losses of $3 \%$ occurring after $72 \mathrm{~h}$ of irradiation. Thus, the effect of irradiation on fruit physiology was minimal.

Expt. 2. Effect of leaves on response of 'Forelle' pear. The decrease in hue angle was greater in exposed 'Forelle' pears without leaves than in fruits with leaves or those covered with foil (Table 3). Anthocyanin synthesis was not, however, induced by these treatments; the change in hue angle indicated a change from green to yellow. The fluctuating temperature $\left(20 / 6{ }^{\circ} \mathrm{C}\right)$ resulted in more yellowing than $\operatorname{did} 20^{\circ} \mathrm{C}$, but did not stimulate anthocyanin synthesis.

Expt.3. 'RedAnjou' and 'Bon Rouge' pear. Since no improvement in color was measured after irradiation of 'Forelle', poorly colored 'Red Anjou' and 'Bon Rouge' pears were irradiated in another attempt to evaluate the potential for postharvest color improvement. The hue angle of 'Red Anjou' pears was not affected by irradiation (data not shown) and that of 'Bon Rouge' slightly decreased after $72 \mathrm{~h}$ of irradiation, but remained unchanged in the dark. Final hue values of 'Bon Rouge' pears were not significantly affected by irradiation.

To the best of our knowledge, responses of pears to postharvest irradiation have not been reported. Dussi et al. (1995) tested light qual- ity on 'Sensation Red Bartlett' pears by attaching different filters to the fruit a month prior to harvest. They reported that wrapping fruit in foil (opaque) or the use of filters increased anthocyanin concentrations slightly. This suggests that light intensity during this period was not a critical factor in anthocyanin synthesis. In a bagging experiment, Marais (1995) found that 'Forelle' pears exposed to light for the first $90 \mathrm{~d}$, then bagged, lost all red color and were as green as the fruit that had been bagged for the whole season. However, fruit that were bagged for the first $60 \mathrm{~d}$, and then exposed to sunlight, developed red color if exposed for longer than $30 \mathrm{~d}$ during the period immediately prior to harvest. Perhaps longer irradiation periods at high intensities and at different wavelengths are needed for appreciable anthocyanin synthesis in pears.

\section{Literature Cited}

Arakawa, O., Y. Hori, and R. Ogata. 1985. Relative effectiveness and interaction of ultraviolet-B, red and blue light in anthocyanin synthesis of apple fruit. Physiol. Plant. 64:323-327.

Arakawa, O., Y. Hori, and R. Ogata. 1986. Characteristics of color development and relationship between anthocyanin synthesis and phenylalanine ammonia-lyase activity in 'Starking Delicious', 'Fuji' and 'Mutsu' apple fruits. J. Jpn. Soc. Hort. Sci. 54:424-430.

Arthur, J.M. 1932. Red pigment production in apples by means of artificial light sources. Contrib. Boyce Thompson Inst. 4:1-18.
Bishop, R.C. and R.M. Klein. 1975. Photo-promotion of anthocyanin synthesis in harvested apples. HortScience 10:126-127.

Blankenship, S.M. 1987. Night-temperature effects on rate of apple fruit maturation and fruit quality. Scientia Hort. 33:205-212.

Chalmers, D.J. and J.D. Faragher. 1977. Regulation of anthocyanin synthesis in apple skin. I. Comparison of the effects of cycloheximide, ultraviolet light, wounding and maturity. Austral. J. Plant Physiol. 4:111-121.

Creasy, L.L. 1968. The role of low temperature on anthocyanin synthesis in 'McIntosh' apples. Proc. New York State Hort. Soc. 93:716-724.

Dong, Y.H., D. Mitra, A. Kootstra, C. Lister, and J. Lancaster. 1995. Postharvest stimulation of skin color in 'Royal Gala' apple. J. Amer. Soc. Hort. Sci. 120:95-100.

Dussi, M.C., D. Sugar, and R.E. Wrolstad. 1995. Characterizing and quantifying anthocyanins in red pears and the effect of light quality on fruit color. J. Amer. Soc. Hort. Sci. 120:785-789.

Knee, M. 1972. Anthocyanin, carotenoid, and chlorophyll changes in the peel of 'Cox's Orange Pippin' apples during ripening on and of the tree. J. Expt. Bot. 23:184-196.

Lancaster, J.E. 1992. Regulation of skin color in apples. Crit. Rev. Plant Sci. 10:487-502.

Lancaster, J.E., J.E. Grant, C.E. Lister, and M.C. Taylor. 1994. Skin color in apples-Influence of copigmentation and plastid pigments on shades and darkness of red color in five genotypes. J. Amer. Soc. Hort. Sci. 119:63-69.

Macheix, J., A. Fleuriet, and J. Billot. 1990. Fruit phenolics. CRC Press, Boca Raton, Fla.

Marais, G.F. 1995. Optimisation of the economic biomass production of 'Forelle' pears (Pyrus communis L.). M.Sc. (Agr.) Thesis, Univ. Stellenbosch, Stellenbosch, S. Africa.

McGuire, R.G. 1992. Reporting of objective color measurements. HortScience 27:1254.

Reay, P.F., R.H. Fletcher, and V.J. Thomas. 1998. Chlorophylls, carotenoids and anthocyanin concentrations in the skin of 'Gala' apples during maturation and the influence of foliar applications of nitrogen and magnesium. J. Sci. Food Agr. 76:63-71.

Saks, Y., L. Sonego, and R. Ben-Arie. 1990. Artificial light enhances red pigmentation, but not ripening, of harvested 'Anna' apples. HortScience 25:547-549.

SAS Institute. 1996. SAS/STAT user's guide, vers. 6.12.. SAS Inst., Cary. N.C.

Saure, M.C. 1990. External control of anthocyanin formation in apple. Scientia Hort. 42:181-218.

Siegelman, H.W. and S.B. Hendricks. 1958. Photocontrol of anthocyanin synthesis in apple skin. Plant Physiol. 33:185-190.

Viljoen, M.M. 1996. Peel pigmentation studies in apples and pears. M.Sc. (Agr.) Thesis, Univ. Stellenbosch, Stellenbosch, S. Africa. 